\title{
The Development Of E-Learning Instruments-Based For Bahasa Indonesia's Subject In Elementary School Education Undergraduate Program Of Universitas Negeri Medan
}

\author{
Faisal $^{1}$, Erlinda Simanungkalit ${ }^{2}$, Stelly Martha Lova ${ }^{3}$ \\ \{faisalpendas@gmail.com ${ }^{1 *}$, erlinda@unimed.ac.id ${ }^{2}$, stellylova77@gmail.com ${ }^{3}$ \} \\ 1,2,3Faculty of Education, Universitas Negeri Medan, Indonesia ${ }^{1,2,3}$ \\ *faisalpendas@gmail.com
}

\begin{abstract}
This research is a research development that aims to produce products, in the form of: the development of E-Learning based learning design in Indonesian language skills courses in the Elementary School Teacher Education Study Program, Universitas Negeri Medan. This development is based on the 4D model (Define, Design, Development, and Disseminate) which emphasizes the needs of users according to the context (lecturers and students). Through theoretical studies and field studies, in the first phase produced a draft of an E-Learning based learning design on Indonesian language skills courses in the Elementary School Teacher Education Study Program covering syllabus, teaching materials, and authentic assessment. In the second stage, the development of products that have been produced is carried out through tests of validity, practicality, and effectiveness. At this stage the developed learning design is reflected and revised according to user needs based on the trials conducted. The results showed that the developed learning design was declared valid, practical, and effective in the use of learning Indonesian language skills in the Elementary School Teacher Education Study Program, Medan State University.
\end{abstract}

Keywords: e-learning, learning design, Indonesian language skills

\section{Introduction}

Today's digital age, humans can learn anytime and anywhere. In this case, learning is authentic and based on an individual. Nevertheless, learning strategies that are often used today are traditional learning, namely class-based learning (classical) using the lecture method [1]. In classical learning, student learning processes are bound by the dimensions of space and time, meaning that students must be in the same space and time as their classmates and lecturers to conduct learning activities. Therefore, it is necessary to find alternatives for classical learning that can overcome these problems without eliminating the feeling of social ties between students and classmates as well as between students and lecturers. If the lecture is the only learning method, students' critical thinking skills become less honed because students are not accustomed to thinking outside the context delivered by the lecturer and become passive in choosing additional learning resources outside the learning resources provided by the lecturer. Though lecturers should not be the only source of learning, especially in today's 
digital era, where learning resources can be obtained relatively easily through the help of information technology $[2,3]$.

It is undeniable that the digital era has a positive impact on the world of education, for example is the emergence of alternative sources of learning and learning media. Learning that used to only be done in the classroom, has now begun to be replaced by online means. Online Learning is the implementation of teaching and learning which is fully carried out with the help of internet technology and does not require any face to face activities. In this learning, students can learn from anywhere and can be done synchronously (directly) or asynchronously (indirectly) $[4,5,6]$.

Responding to the explanation above, Medan State University has made a policy on strengthening the implementation of the KKNI-based curriculum by using a blended learning model in every learning. This policy requires that learning not only be carried out through face-to-face processes, but can also be done online / online with a minimum of 4 meetings out of 16 planned meetings. In this way it is hoped that students and lecturers will not be separated between space and time so that the learning process can be carried out at any time without having to face-to-face in classical meetings.

In an effort to support the above policy, Medan State University provides direction so that each course in each Study Program develops a learning design that leads to gradual and continuous blended learning. The intended learning design is in the form of Learning Plans, teaching materials, and authentic assessment. Thus, each course provides space for students to study independently without having to face-to-face with the lecturer supporting the course.

However, at present the design of learning especially Indonesian language skills courses in Primary Schools in the Primary School Teacher Education study program has not been designed in the form of blended learning. Learning tools still use the Competency Based Curriculum and are still designed in the form of face-to-face learning. Thus, when referring to the prerequisites of blended learning at Medan State University, Indonesian language skills courses in Elementary Schools still need further development especially in developing learning designs in accordance with the demands of the blended learning model at Medan State University.

Efforts to overcome the above problems can be done by developing an E-Learning based learning design as an effort to strengthen the implementation of the KKNI curriculum oriented towards blended learning at Medan State University. In this way, the learning design developed in the form of syllabus and Learning Plans, teaching materials, and authentic assessment can be accessed independently by students without being limited by time and space.

\section{Research Method}

This research is a research and development. Development research is research that is designed in a structured and systematic way to develop a product through certain stages and evaluations to test the level of validity and effectiveness in using it. The product produced in development research is different from the development intended simply. Simple development is simply designed without any revision as input from various experts. This has an impact on the level of validity and effectiveness of the resulting product less felt in its use.

Seels and Richey [7] explain that, "Developmental research, as opposed to simple instructional development, has been defined as" the systematic study of designing, developing, 
and evaluating instructional programs, processes and products that must meet the criteria of internal consistency and effectiveness." That is, development research as distinguished from simple learning development, is defined as a systematic study to design, develop, and evaluate programs, processes, and learning outcomes that must meet internal consistency and effectiveness criteria. Thus, the development is done by using a development model.

The development model used in this study is a 4-D (four D models) development model. The stages of the 4-D model include: defining, designing, developing, and disseminating [8].

The development procedures carried out in this study can be seen in Figure 1 below.

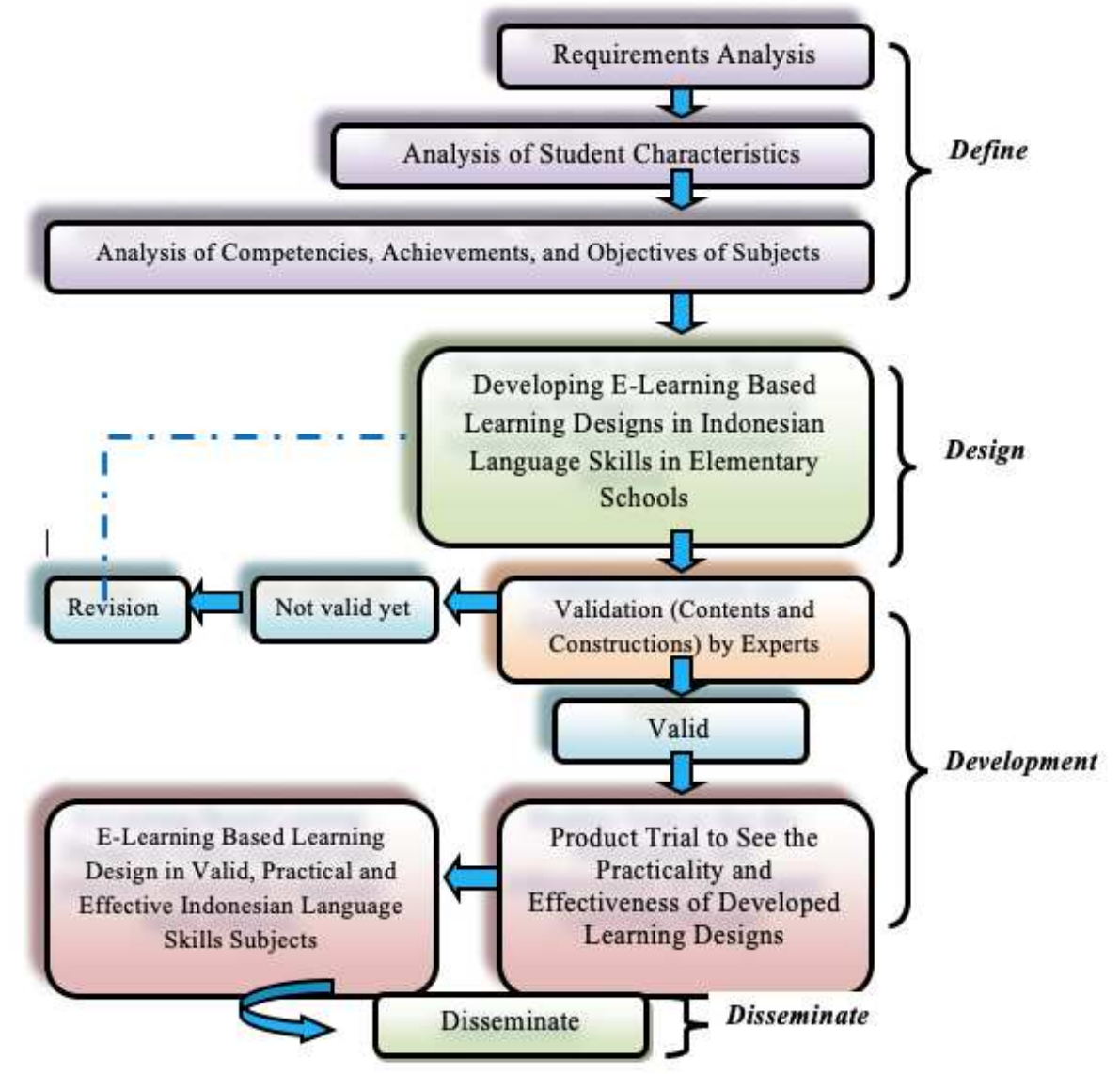

Fig 1. Procedures for Developing E-Learning Based Learning Designs

The stages of developing an E-Learning based learning design in Indonesian language skills courses based on Figure 2.1 that have been displayed can be detailed as follows:

1. The definition phase aims to establish and define learning design requirements that are consistent with the research objectives, namely the development of E-Learning-based learning designs in Indonesian language skills courses in Elementary School Teacher Education, Medan State University.

2. The design phase is designing an e-learning based learning design in accordance with the determination and definition in stage 1. 
3. The development stage includes testing the validity, practicality, and effectiveness of the E-Learning based learning design that was developed.

4. The deployment phase is the final stage of the 4-D step offered. After being validated and tested for practicality and effectiveness in a particular class, a broader scale of distribution is carried out.

The data analysis technique used to process research data is quantitative and qualitative descriptive data analysis. Expert test and small group test data from the questionnaire were analyzed in percentages and explained qualitatively. Field test / user test data in the form of learning processes in the development environment were analyzed by analyzing qualitative data flow models by applying the principle of multipurpose. In this case what matters is how an analysis technique can be used to support problem solving [9].

Analysis activities, including: data reduction, data presentation, and drawing conclusions or verification. Data reduction activities include classification and coding according to the type of data. Presentation of data in the form of description descriptions, tables, diagrams, pictures or other visual forms. The data that has been presented is verified, interpreted, and concluded. Targets for data analysis include levels of observation, description, and explanation. At the level of observation the data are selected, categorized, and coded. At the level of description the data is presented in units of patterns, units of events, units of inclination, or units of meaning. At the explanatory level the analysis is directed at the effectiveness of the trials.

\section{Result and Discussion}

\section{a. Results}

Validity of Learning Plans and Assessment Guidelines

Data on the results of the validation of the Learning Plan and guidelines for assessment from expert validators are presented in Table 1 below.

Table 1 Results of Validation for Learning Plans and Assessment Guidelines

\begin{tabular}{clcc}
\hline No & \multicolumn{1}{c}{ Rated Aspect } & $\begin{array}{c}\text { Validation } \\
\text { Value }\end{array}$ & Category \\
\hline 1. & Identity & 4.00 & Very Valid \\
2. & Formulation of Learning Objectives & 3.78 & Very Valid \\
3. & Selection of Learning Materials & 3.67 & Very Valid \\
4. & Methods and Details of Learning Steps & 3.47 & Valid \\
5. & Selection of Learning Resources & 3.59 & Very Valid \\
6. & Assessment & 3.59 & Very Valid \\
\hline \multicolumn{2}{c}{ Average } & $\mathbf{3 . 6 3}$ & Very Valid \\
\hline
\end{tabular}

The results of the validation of the Learning Plan assessed by experts such as in Table 3.1 described can be seen that the average validation results are 3.63 in the very valid category. Based on the aspects assessed obtained that the inclusion of identity is 4.00 , the formulation of learning objectives 3.78 , the selection of learning materials 3.67 , the methods and details of the learning steps 3.47, the choice of learning resources 3.59, and the assessment of 3.59 .

Looking at the assessment above, it was found that the Learning Plan and assessment guidelines were well used as a guide to the implementation of the learning process of 
Indonesian language courses in Elementary Schools. The steps compiled can guide the lecturer to facilitate students in conducting various learning activities in accordance with the learning stages of each meeting.

\section{Validity of Teaching Materials}

Data on the validation of teaching materials from expert validators is presented in Table 2 below.

Table 2 Results of Validation of Teaching Materials by Expert Validators

\begin{tabular}{|c|c|c|c|}
\hline No & Rated Aspect & $\begin{array}{c}\text { Validation } \\
\text { Value }\end{array}$ & Category \\
\hline 1. & Content Feasibility & 3.67 & Very Valid \\
\hline 2. & Linguistic & 3.59 & Very Valid \\
\hline 3. & Presentation & 3.67 & Very Valid \\
\hline 4. & Grafting & 3.42 & Valid \\
\hline \multicolumn{2}{|r|}{ Average } & 3.60 & Very Valid \\
\hline
\end{tabular}

The results of the validation of teaching materials were assessed by experts in Table 2 above, it was found that the average validation results were 3.60 in the very valid category. Based on the aspects assessed are obtained the following description: the feasibility of the contents of 3.67 , the language of 3.59 , the presentation of 3.67 , and the graphic presentation of 3.42 .

Based on the previous assessment, it shows that the developed teaching material is valid. This means that the developed teaching material is good and can be used as a learning resource for students in Indonesian language skills courses in elementary schools. Teaching materials compiled help students understand the concepts and application of Indonesian language skills in elementary schools.

\section{WEB Validity}

WEB validation data results from expert validators are presented in Table 3 below.

Table 3 Results of WEB Validation by Expert Validators

\begin{tabular}{|c|c|c|c|}
\hline No & Rated Aspect & $\begin{array}{c}\text { Validation } \\
\text { Value } \\
\end{array}$ & Category \\
\hline 1. & WEB Content Eligibility & 3.78 & Very Valid \\
\hline 2. & Linguistic & 3.67 & Very Valid \\
\hline 3. & Presentation & 3.80 & Very Valid \\
\hline 4. & WEB Display & 3.59 & Very Valid \\
\hline \multicolumn{2}{|r|}{ Average } & 3.72 & Very Valid \\
\hline
\end{tabular}

Based on the data in Table 3 above, a general description of the validator is obtained, namely 3.72 with a very valid category. From every aspect observed, it was found that the feasibility of web content was 3.78, linguistic 3.67, presentation 3.80, and web display 3.59 . Based on these data, it can be concluded that the developed WEB was declared valid for use in Indonesian language skills courses in Elementary Schools.

\section{Practicality of Learning Plans and Assessment Guidelines}

Test the implementation of the Learning Plan and assessment guidelines known through observation. Observations were made using instruments for observing the implementation of the Learning Plan and Assessment Guidelines. 
Based on observations of the implementation of the Learning Plan and Assessment Guidelines, the average scores in the very practical category are obtained. For more details, see Table 4 below.

Table 4 Observation Results of the Implementation of Learning Plans and Assessment Guidelines

\begin{tabular}{clcc}
\hline No & Rated Aspect & $\begin{array}{c}\text { Observer } \\
\text { Judgment }\end{array}$ & Category \\
\hline A. & Preliminary & 3.42 & Practical \\
B. & Core Activities & 3.50 & Very Practical \\
C. & Closing & 3.60 & Very Practical \\
\hline \multicolumn{2}{c}{ Average } & $\mathbf{3 . 5 0}$ & Very Practical \\
\hline
\end{tabular}

Table 3.4 shows the average ability of lecturers in implementing the Learning Plan and the assessment guidelines used are categorized as very practical as indicated by the evaluation of the implementation of the Learning Plan and the assessment guidelines by two observers as observers.

\section{Practicality of Teaching Materials}

The result of observation of the intended use of the material is the level of ease of students using the developed teaching material. There are several aspects observed when students use teaching materials, including: (a) students easily understand the various concepts of teaching materials, (b) students easily understand the steps of activities that exist in teaching materials, (c) students are interested and motivated to learn from the design of the teaching material displayed, and (d) active and enthusiastic students working on the assignments that are in the teaching material. For more details, it can be described as follows.

The results of observations on the ease of students understanding various concepts that exist in teaching materials are seen when students observe and read teaching materials. Students do not get significant obstacles in understanding various concepts. The aspect of the ease of students understanding the steps of activities contained in teaching materials is also the same as the ease in understanding the concepts contained in teaching materials. Aspects of student interest and enthusiasm for teaching materials can be observed from the interest of students reading the teaching materials provided. Students look happy to participate in various activities contained in teaching materials. Furthermore, students also look active and enthusiastic about participating in various activities and assignments in the teaching materials provided.

Based on the explanation above, it can be concluded that students find it easy to understand concepts and do various tasks in teaching materials. Thus, students do not have significant obstacles using teaching materials provided in Indonesian language skills courses in Elementary Schools.

\section{Practicality of WEB}

The practicality of using WEB can be obtained from the results of interviews with lecturers who tested the device that was developed The implementation of using WEB was carried out with unstructured interviews. This means that the question develops according to the answer of the respondent (lecturer) after being given a question. The results of interviews with students and lecturers show that the WEB used is easy to use in the learning process.

Attitude Assessment

Attitude assessment (character) is an assessment of student behavior when the lecture process takes place. Through the lecture process, it is expected that students will be able to 
show attitudes that will be assessed, including: ethics of communication, responsibility, and cooperation. Thus, the assessment of the effectiveness of the learning process is not only on aspects of activities and outcomes, but can show a better attitude.

The determination of the completeness of the attitude contained in this study was adopted from the KKNI attitude assessment by Medan State University with a range of grades 1-4. The results of attitude assessment can be seen in the following Table 5.

Table 5. Results of Attitude Assessment (Character) of Students

\begin{tabular}{|c|c|c|c|}
\hline No & Rated Aspect & Value & Category \\
\hline 1. & Communication Ethics & 3.25 & Good \\
\hline 2. & Responsible & 3.21 & Good \\
\hline 3. & Cooperation & 3.25 & Good \\
\hline & Average & 3.24 & Good \\
\hline
\end{tabular}

Based on Table 5 above, it can be concluded that students are accustomed to showing good attitudes in terms of communication ethics, responsibilities, and cooperation.

\section{Knowledge Assessment}

Knowledge assessment is an assessment of understanding of lecture material. This assessment can be measured through evaluation questions provided related to the content of lecture material. The evaluation questions provided are an evaluation component of the Learning Plan and developed teaching materials. The questions given were 10 items in the form of multiple choice, 5 items in the form of contents, and 5 questions in the form of essays.

Determination of mastery learning outcomes using learning completeness criteria. The completeness of student learning outcomes individually seen from the formative test results provided and compared with the completeness criteria in each class tested. Detailed learning outcomes can be in Table 6 below.

Table 6 Assessment of Student Learning Outcomes

\begin{tabular}{ccccc}
\hline No & $\begin{array}{c}\text { Number of Test } \\
\text { Participants }\end{array}$ & $\begin{array}{c}\text { Amount of } \\
\text { Values }\end{array}$ & Average & $\begin{array}{c}\text { Completeness } \\
(\%)\end{array}$ \\
\hline 1. & 24 & 1906.4 & 79.43 & $87.5 \%$ \\
\hline
\end{tabular}

Based on Table 3.6, it is obtained that the design of learning can help students understand the lecture material in its entirety. This can be obtained from the acquisition of learning outcomes obtained by an average of 79.43. Meanwhile, completeness is classically obtained $87.5 \%$, meaning that out of 24 students there are 21 people who have completed and 3 people who have not yet completed.

\section{Skills Assessment}

Skills assessment is an assessment that is observed to see student skills when the learning process of reading is carried out. Students fill out the activity sheets that have been provided. The results of the completed worksheets will be assessed using the reading skills assessment rubric. Then, the results assessment is an assessment of students' understanding of the reading material provided. Students are given evaluation questions related to reading material then the results are processed using scoring guidelines. Detailed observational data can be seen in Table 7 below. 
Table 7 Results of Reading Skills Assessment Process

\begin{tabular}{|c|c|c|c|}
\hline No & Rated Aspect & $\begin{array}{c}\text { Value } \\
(\%)\end{array}$ & Category \\
\hline \multicolumn{4}{|c|}{ Pre Reading } \\
\hline & Predict the content of the reading & 95.8 & Very High \\
\hline \multicolumn{4}{|c|}{ Reading } \\
\hline 2 & $\begin{array}{l}\text { Fill in the meaning of words that are not yet } \\
\text { understood }\end{array}$ & 86.1 & Very High \\
\hline 3. & Test predictions & 100 & Very High \\
\hline 4. & Respond to information from read text & 73.6 & High \\
\hline \multicolumn{4}{|c|}{ Post Reading } \\
\hline 5. & Summarize the contents of the reading & 79.2 & High \\
\hline & Average & 86.93 & Very High \\
\hline
\end{tabular}

Based on Table 3.7 described, it was found that the average value of the process assessment results was $86.93 \%$ with a very high category. That is, when the learning process takes place, student activities are very good at understanding and using teaching materials that are developed. There are three main stages that can be observed based on the table above, namely the pre-reading, when reading, and post-reading stages. For more details, it can be described as follows.

At the pre-reading stage, the assessed aspect is the activity of predicting the content of the reading before reading. In the activity of predicting the content of the reading obtained an average value of $95.8 \%$ with a very high category. This gives an illustration that most students fill in the prediction sheet for the overall contents of the text. They predict reading through supporting titles and images related to the reading text to be read on teaching material.

At the reading stage, three main aspects are assessed, namely filling in the meaning of words that are not yet understood, testing predictions, and responding to information from the text being read. In the activities of filling in the meaning of words that are not yet understood, an average value of $86.1 \%$ is obtained with a very high category. Furthermore, the prediction testing activities obtained an average value of $100 \%$ with a very high category, and responding to information based on the text read obtained an average value of $73.6 \%$ with a high category. Based on the explanation, it can be concluded that students can follow the reading process activities well in understanding the contents of the reading.

In the post-reading stage, the aspect assessed is the activity of summarizing the contents of the reading. In this activity an average value of $79.2 \%$ was obtained with a high category. Students have been able to summarize the contents of the text as a whole nicely coherently. The contents of the summary that has been made can also describe the overall contents of the text. Thus, at the post reading stage, it can follow the activities well.

\section{b. Discussion}

\section{Validity of Learning Design}

Learning designs that have been developed are said to be valid if they meet certain criteria. The characteristics of the product are said to be valid if they reflect the state of the art of knowledge. This is what is said with content validation. Furthermore, the components of these products must be consistent with each other (construct validity). Therefore, the validation of the learning design in this study emphasizes content validity and construct validity [9]. 
The validity of the content has been declared valid by the validator because the learning design of the Learning Plan and the assessment guidelines, teaching materials, and WEB developed are in accordance with the actual material and conditions in Indonesian language skills courses in Elementary Schools. The construct validity has also been declared valid by the validator. This is because the learning design construct developed has met the terms and conditions of the preparation of the learning design. Based on the validation assessment data analysis by the validator, the learning design developed is classified as very valid. The following will be explained clearly the description of each learning design that has been developed.

\section{Learning Plans and Assessment Guidelines}

The results of the analysis of the validation data for the Learning Plan and the assessment guidelines show an average value of 3.63 by the expert validator. Based on the predetermined categories, the Learning Plan and assessment guidelines that have been developed fall into the very valid category. The Learning Plan and assessment guidelines that have been developed illustrate the suitability of all components and activities and the concepts contained therein. This conformity can be seen from the indicators and learning objectives formulated, the material chosen, the description of the strategies used, the steps of learning, the media and learning resources, as well as the assessment conducted. That is, as a whole has been able to describe the components of the Learning Plan in accordance with the development of the KKNI Medan State University.

\section{Teaching Materials}

Based on the results of the analysis of the validation of teaching materials obtained an average value of 3.60. If seen from the predetermined categories, the teaching materials that have been developed belong to the very valid category. Therefore, it can be concluded that the developed teaching materials are in accordance with the demands of the curriculum. Presentation of material is in accordance with the indicators that are formulated and in accordance with student development.

The contents of teaching materials are also in accordance with Indonesian language lecture materials in Elementary Schools. Various concepts and elaboration of the tasks contained in teaching materials make it easy for students to understand the contents of the reading appropriately. The contents of teaching materials have been able to achieve the selected competencies. In addition, the use of language in teaching materials uses simple and clear sentences so that it is easily understood by every student. Sentence by sentence using the correct spelling. Then, the teaching material developed is designed with attractive colors so that it can motivate students to follow the learning process well. Thus, it can be concluded that the developed teaching material has been declared valid and can be used in the process of lecturing Indonesian language skills in Elementary Schools.

\section{WEB}

In general, the level of validity of the WEB is based on the evaluation of the validator, which is 3.72 with a very valid category. From every aspect observed, it was found that the feasibility of the WB content was 3.78 , the language was 3.67 , the presentation was 3.80 , and the WEB display was 3.59. Based on these data, it can be concluded that the developed WEB was declared valid for use in Indonesian language skills courses in Elementary Schools. 


\section{Practicality of Learning Design}

The level of practicality to see the extent to which lecturers and students can use the learning design properly. A learning design is said to be practical if the learning design can be used easily by educators and students in learning [9]. To see whether the learning design that has been developed is practical or not, a trial is conducted on Grade A students in the Elementary School Teacher Education Study Program, Medan State University.

\section{Implementation of Learning Plans and Assessment Guidelines}

The results of observations of the implementation of the Learning Plan and assessment guidelines show that learning is carried out in accordance with the plans that have been made. This can be seen from the results of observations of the implementation of the Learning Plan and assessment guidelines which are very good. This data shows that the Learning Plan and assessment guidelines developed are very practical to be used in lectures. During the trial, there were no significant obstacles found by the lecturer in carrying out the learning process although a little lack of time, but can be overcome by more optimal classroom conditioning.

\section{Use of Teaching Materials}

The result of observation referred to is the level of ease of students in using teaching material that was developed. Based on observations generally obtained a description of the activities that students find it easy to use teaching materials developed. Students find it easy to understand the various concepts and steps of activities that exist in teaching materials. Then, students seemed to feel interested and enthusiastic and were actively involved in doing various tasks in the teaching material.

\section{Use of WEB}

The results of the analysis are based on the results of interviews with lecturers after using WEB in learning to get responses and positive responses. Researchers conduct unstructured interviews meaning questions develop according to the teacher's previous answers. Based on the distribution of lecturer answers from the interview results, it is explained that the WEB developed is easy to use in the learning process. The teacher feels it is easy to give material to students because it provides more detailed and clear stages in helping students understand the contents of WEB-based e-lecture material. Thus, it can be concluded that the WEB that has been developed is practically used in lectures.

\section{Effectiveness of Learning Designs}

Product quality or development results can be determined based on the validity, practicality, and effectiveness of the developed learning design. The effectiveness aspect can be done if the product is valid and practical. The effectiveness of the learning program is characterized by the following characteristics: (a) successfully leads students to achieve instructional goals that have been set, (b) provides an attractive learning experience, actively involves students so as to support the achievement of instructional goals, (c) has the means means that support the learning process [10].

The effectiveness of learning design can be seen through the assessment of student activities, attitudes, knowledge, and skills. Learning design is said to be effective if the results obtained by students are as expected. When viewed from the aspect of activities, learning design is said to be effective if it gets a good category. Whereas if seen from the aspect of assessment of students' knowledge and skills it is said to be effective if the mastery of student 
learning outcomes obtains classical completeness $\geq 75 \%$. For more details can be seen in the following explanation.

\begin{abstract}
Attitude Assessment
Attitude assessment is an assessment of student behavior when the learning process is carried out. There are three aspects of attitude that are assessed, among others: communication ethics, responsibility, and cooperation. The assessment guidelines adopted were from the KKNI attitude assessment guidelines by Medan State University.

Based on the recapitulation of attitudes, the average value obtained is 3.24 with a good category. That is, if guided by the character education assessment guide, students are accustomed to having a good attitude in the ethics of communication, responsibility, and cooperation.
\end{abstract}

\title{
Knowledge Assessment
}

Knowledge assessment is to see how far students can understand the lecture material in full. Students are directed to answer evaluation questions related to reading texts. From the description of the results obtained, individual and classical completeness is seen. Individual completeness sees the limits of the minimum Minimum Mastery Criteria that are set that is minimal B. While classical completeness, a learning process is said to be effective if it reaches $\geq 75 \%$.

Based on the acquisition of learning outcomes obtained an average value of 79.43 with the Good category. Then, the complete students are 21 people or if they are presented at $87.5 \%$. While there are not yet completed 3 people or if present is $12.5 \%$. By paying attention to the acquisition of results and the achievement of completeness, the learning process using the developed learning design has been effectively used.

\section{Skills Assessment}

Skills assessment is done by looking at the overall reading stages, namely the prereading, when reading, and post-reading stages. In the pre-reading stage, students are directed to predict the reading content. At the time of reading, there are three aspects to be assessed, namely filling in the meaning of words that are not yet understood, testing predictions, and responding to information from the text being read. Then, in the post reading stage, students are directed to summarize the contents of the reading in a coherent and intact way.

In the pre-reading stage, students can predict the contents of the text in very good categories. That is, students do not have significant obstacles when directed to predict the contents of reading texts. They are able to fill in and answer every question contained in the activity sheet provided, although there are some incorrect answers. However, in general at the pre-reading stage, especially in the activity of predicting the reading content can be done with the maximum and in accordance with the expected results.

At the reading stage, students can fill in the meaning of words that are not well understood, although there are some students who have not been able to fill in completely. To overcome this, students are given the freedom to ask questions related to the meaning of words that are not yet understood. Prediction testing can also work well. Students can prove the prediction that they have done before so they get a true picture of the contents of the text. Furthermore, there was a slight decrease in the activity of responding to information from the text that was read. Students give unclear responses so that the meaning of the responses given is not well understood. Students raise a lot of problems, but they are less able to respond according to the problems raised. However, this aspect can be said to be going well. This is 
stated by looking at the results of the observation sheet that activities respond to information from the text that is read into the high category.

In the post-reading stage, students can summarize well. The contents of the summary can be arranged coherently and its contents can provide a complete description of the contents of the text. Nevertheless, there are main things that need to be considered in this activity, namely the use of spelling summaries that have been written still need further guidance. Thus, it is not only the content and the content that is considered, but the spelling accuracy that can support the effectiveness of the summary provided.

Seeing the explanation of the three stages above, it can be concluded that the use of the developed learning design can support maximum learning activities. That is, students can go through stages or process activities in each step well. Thus, in general the process of activities that students go through scores with a very high average.

\section{Conclusion}

Based on the development and testing of learning designs that have been developed, the following conclusions are obtained.

a. Learning designs have been produced in the form of Learning Plans and assessment guidelines, teaching materials, and WEB with average categories that are very valid. This can be seen based on the results of the learning design validation by expert validators that have been implemented. These results illustrate that the learning design developed is valid and can be used in the lecture process.

b. Practicality of overall learning design in the very practical category. This can be seen from the results of observing the implementation of the Plan and guidelines for evaluating lecturers who teach, lecturer and student responses, observations, and interviews that have been conducted. These results illustrate that the use of instructional design by lecturers is very practical and can help in carrying out the lecture process in Indonesian language skills courses in Elementary Schools.

c. The effectiveness of the use of learning designs can be known through observing student activities, attitude assessment, knowledge assessment, and assessment of student skills. The results of observing activities, evaluating attitudes, evaluating knowledge, and evaluating student skills provide a very good picture of the results, meaning that the use of design in learning has been effectively implemented.

\section{References}

[1] Yazdi, M. E-Learning sebagai Media Pembelajaran Interaktif Berbasis Teknologi Informasi. In FORISTEK: Forum Teknik Elektro dan Teknologi Informasi (Vol. 2, No. 1). (2012).

[2] Kristanto, A. The Development of Instructional Materials E-Learning Based on Blended Learning. International Education Studies, 10(7), 10-17. (2017).

[3] Wijaya, M. Pengembangan Model Pembelajaran E-Learning Berbasis Web dengan Prinsip E-Pedagogy dalam Meningkatkan Hasil Belajar. Jurnal Pendidikan Penabur, 11(19), 2027. (2012). 
[4] Sari, A. R. Strategi Blended Learning untuk Peningkatan Kemandirian Belajar dan Kemampuan Critical Thinking Mahasiswa di Era Digital. Jurnal Pendidikan Akuntansi Indonesia, 11(2). (2013).

[5] Purnomo, A., Ratnawati, N., \& Aristin, N. F. Pengembangan Pembelajaran Blended Learning pada Generasi Z. Jurnal Teori dan Praksis Pembelajaran IPS, 1(1), 70-76. (2016).

[6] Sari, M. Blended Learning, Model Pembelajaran Abad ke-21 di Perguruan Tinggi. Ta'dib, 17(2), 126-136. (2016).

[7] Setyosari, Punaji. Metode Penelitian Pendidikan dan Pengembangan. Jakarta: Kencana Prenada Media Group. (2010).

[8] Sugiyono. Metode Penelitian Pendidikan Pendidikan Kuantitatif, Kualitatif, dan R\&D. Bandung: Alfabeta. (2009).

[9] Plomp, T. dan Nieveen, N. (Eds). An Introduction to Educational Design Research. Enschede: Netherlands Institute for Curriculum Development (SLO). (2007).

[10] Firman, Harry. Assessment of Learning Outcomes in Teaching. Bandung: Universitas Pendidikan Indonesia. (2010). 